ISSN 1678-3921

Journal homepage: www.embrapa.br/pab

For manuscript submission and journal contents, access: www.scielo.br/pab

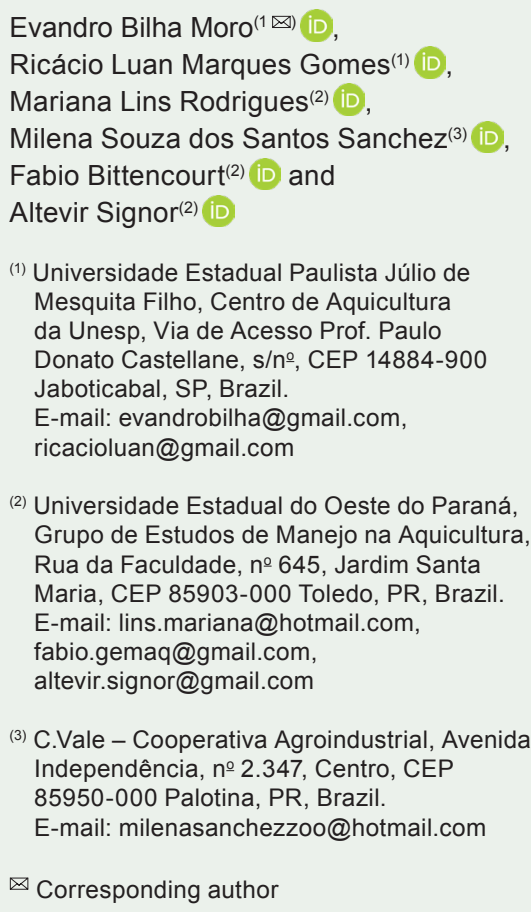

(2) Universidade Estadual do Oeste do Paraná, Grupo de Estudos de Manejo na Aquicultura, Rua da Faculdade, № 645, Jardim Santa Maria, CEP 85903-000 Toledo, PR, Brazil. E-mail: lins.mariana@hotmail.com, fabio.gemaq@gmail.com altevir.signor@gmail.com

(3) C.Vale - Cooperativa Agroindustrial, Avenida Independência, ํㅜ 2.347, Centro, CEP 85950-000 Palotina, PR, Brazil. E-mail: milenasanchezzoo@hotmail.com

$\bowtie$ Corresponding author

Received

July 30, 2019

Accepted

August 24, 2020

How to cite

MORO, E.B.; GOMES, R.L.M.; RODRIGUES, M.L.; SANCHEZ, M.S. dos S.; BITTENCOURT, F.; SIGNOR, A. Performance of pacu juveniles fed diets supplemented with L-carnitine. Pesquisa Agropecuária Brasileira, v. 55 e01583, 2020. DOI: https://doi.org/10.1590/ S1678-3921.pab2020.v55.01583.

\section{Performance of pacu juveniles fed diets supplemented with L-carnitine}

\begin{abstract}
The objective of this work was to determine the effect of L-carnitine supplementation on the productive performance and physiology of juvenile pacu (Piaractus mesopotamicus). A total of $288 \mathrm{pacu}$, with an initial average weight of $9.62 \pm 0.74 \mathrm{~g}$, were fed experimental diets supplemented with $400,800,1,200$, 1,600 , and $2,000 \mathrm{mg} \mathrm{kg}^{-1} \mathrm{~L}$-carnitine and a control diet (without supplementation), for 128 days. The following were evaluated: growth performance; carcass centesimal composition; intestinal, muscle, and hepatic histomorphologies; and oxidative stress. The fish hepatosomatic and viscerosomatic fat indexes increased with the inclusion of L-carnitine in the diets. The evaluation of carcass centesimal composition showed that the diets supplemented with $2,000 \mathrm{mg} \mathrm{kg}^{-1}$ $\mathrm{L}$-carnitine caused a reduction in protein content and an increase in that of ethereal extract. Intestinal histomorphology indicated changes in the villi with L-carnitine supplementation. Moreover, hepatic lipid peroxidation occurred with the inclusion of $2,000 \mathrm{mg} \mathrm{kg}^{-1} \mathrm{~L}$-carnitine. The supplementation with $\mathrm{L}$-carnitine in the diets of pacu juveniles does not influence the development of the fish until the rate of $1,600 \mathrm{mg} \mathrm{kg}^{-1}$. However, high carcass lipid levels, as well as an increase in the hepatosomatic and viscerosomatic fat indexes, are observed in fish fed diets containing $2,000 \mathrm{mg} \mathrm{kg}^{-1}$.
\end{abstract}

Index terms: Piaractus mesopotamicus, animal nutrition, carcass composition, histomorphology, oxidative stress.

\section{Desempenho de juvenis de pacu alimentados com rações suplementadas com L-carnitina}

Resumo - O objetivo deste trabalho foi determinar o efeito da suplementação de L-carnitina no desempenho produtivo e na fisiologia de juvenis de pacu (Piaractus mesopotamicus). Um total de 288 pacus, com peso inicial médio de $9,62 \pm 0,74 \mathrm{~g}$, foram alimentados com dietas experimentais suplementadas com $400,800,1.200,1.600$ e $2.000 \mathrm{mg} \mathrm{kg}^{-1}$ de L-carnitina e com uma dieta controle (sem suplementação), por 128 dias. Foram avaliados: desempenho produtivo; composição centesimal da carcaça; histomorfologias intestinal, muscular e hepática; e estresse oxidativo. Os índices hepatossomático e de gordura viscerossomática dos peixes aumentaram com a inclusão de L-carnitina nas rações. A avaliação da composição centesimal da carcaça mostrou que as dietas suplementadas com $2.000 \mathrm{mg} \mathrm{kg}^{-1}$ de L-carnitina causaram redução no conteúdo de proteína e aumento no de extrato etéreo. A histomorfologia intestinal indicou alterações nas vilosidades com a suplementação de L-carnitina. Além disso, a peroxidação lipídica hepática ocorreu com a inclusão de $2.000 \mathrm{mg} \mathrm{kg}^{-1}$ de L-carnitina. A suplementação de L-carnitina em dietas para juvenis de pacu não influencia o desenvolvimento dos peixes até a dose de $1.600 \mathrm{mg} \mathrm{kg}^{-1}$. Entretanto, observam-se elevados níveis de lipídeos na carcaça, assim como aumento nos índices hepatossomáticos e de gordura viscerossomática, em peixes alimentados com rações contendo $2.000 \mathrm{mg} \mathrm{kg}^{-1}$.

Termos para indexação: Piaractus mesopotamicus, nutrição animal, composição da carcaça, histomorfologia, estresse oxidativo. 


\section{Introduction}

An important challenge in aquaculture practices is improving fish sustainable production, to reduce costs and minimize negative effects on the environment. In fish production, feeding represents the highest cost, reaching up to $70 \%$ of the total (Nass et al., 2020). This shows the need of assessing the effects of additives and/ or supplements, such as L-carnitine, on fish growth and physiology (Rodrigues et al., 2015).

L-carnitine is synthesized from lysine and methionine with the help of vitamin C (Harpaz, 2005). This molecule has attracted interest because it is a multi-physiological additive, with a considerable positive effect on the growth and lipid metabolism of some fish species (Mohseni \& Ozorio, 2014). It acts in the transport of long-chain fatty acids, through the mitochondrial membrane, for the oxidation and production of adenosine triphosphate in peripheral tissues (Longo et al., 2016). Its highest concentration is in the skeletal and cardiac musculatures (Harpaz, 2005). When there is a deficiency in L-carnitine, hepatic lipid oxidation is reduced, diverting fatty acids for the synthesis of triacylglycerol in the liver (WrayCahen et al., 2004).

L-carnitine can improve the productive performance of fish when included in their diet. As an amine, it has a protein-sparing effect, directing dietary and body lipids to maintaining body energy (Tonini et al., 2011). It can also prevent the formation of free radicals, minimizing the peroxidation of membrane lipids and the aggression to tissue and membrane proteins (Safari et al., 2015). In Nile tilapia (Oreochromis niloticus Linnaeus, 1758) fingerlings, the inclusion of $450 \mathrm{mg} \mathrm{kg}^{-1} \mathrm{~L}$-carnitine in the diets was able to reduce protein requirement from 30 to $20 \%$, without affecting productive performance (El-Sayed et al., 2010).

Several authors have reported the positive effects of L-carnitine on some fish species, including: improved growth, reduction of muscle fat, better response against stress due to confinement, and adaptation to high levels of ammonia and high temperature variations (Gonçalves et al., 2010; Yang et al., 2012). However, the literature also shows contradictory results, which may be related to differences among the studied species, such as experimental conditions, management, and leaching and levels of the supplemented L-carnitine, among others (Gonçalves et al., 2010).
Despite these reports, there are still no known studies on the inclusion of L-carnitine in the diet of pacu (Piaractus mesopotamicus Holmberg, 1887), which is native to South America and has an opportunistic omnivorous food habit, being well adapted to different production systems (Vaz et al., 2000). The species is also one of the most studied in Brazilian aquaculture and the sixth most cultivated in the country (Produção..., 2018). Its main characteristics include: rusticity, adaptability to artificial feeding, and easy management, which provide positive production results (Nunes et al., 2013). However, since the species is considered as a fat fish (Ramos Filho et al., 2008), researches with the aim of reducing its celomatic fat content are vital to improve its performance.

The objective of this work was to determine the effect of L-carnitine supplementation on the productive performance and physiology of juvenile pacu.

\section{Materials and Methods}

The research project was approved by the animal ethics committee of Universidade Estadual do Oeste do Paraná (protocol number 42/17), located in the municipality of Toledo, in the state of Paraná, Brazil. A total of 288 pacu juveniles, with an average initial weight of $9.62 \pm 0.74 \mathrm{~g}$, were distributed in 24 cylindrical-conical tanks with the capacity of $0.5 \mathrm{~m}^{3}$, equipped with a water recirculation system containing a mechanical filter and a central air blower for constant aeration. The experimental design was completely randomized, with six treatments and four replicates (the tanks were the experimental unit), with 12 fish each. Weekly, the following water physical and chemical parameters were measured using the YSI Professional Plus multiparameter meter (YSI Incorporated, Yellow Springs, OH, USA): $\mathrm{pH}$, $7.03 \pm 0.11$; electrical conductivity, $80.7 \pm 0.68 \mu \mathrm{S} \mathrm{cm}^{-1}$; and dissolved oxygen, $8.54 \pm 0.50 \mathrm{mg} \mathrm{L}^{-1}$. Daily, temperature $\left(22.5 \pm 1.6^{\circ} \mathrm{C}\right)$ was measured using a digital thermometer. The values obtained for the water quality parameters are within the production range for the species, but the temperature is at the minimum recommended (Tavares \& Santeiro, 2013).

The experimental diets were formulated as isoenergetic (3,200 kcal kg-1 digestible energy) and isoproteic (23\% digestible protein) (Table 1). Based on National Research Council (NRC, 2011), the treatments were supplemented with $0,400,800,1,200,1,600$, and 
2,000 $\mathrm{mg} \mathrm{kg}^{-1} \mathrm{~L}$-carnitine. The used feed ingredients extruded in the Ex Micro extruder (Exteec Máquinas, were ground individually in a hammer-type grinder, Ribeirão Preto, SP, Brazil), and oven dried at $55^{\circ} \mathrm{C}$ for manually blended according to each formulation, 24 hours. After cooling, the feed was packed in bags

Table 1. Chemical composition of the experimental diets containing different levels of L-carnitine fed to juvenile pacu (Piaractus mesopotamicus).

\begin{tabular}{|c|c|c|c|c|c|c|}
\hline \multirow{2}{*}{$\begin{array}{l}\text { Ingredient } \\
(\%)\end{array}$} & \multicolumn{6}{|c|}{ L-carnitine ( $\left.\mathrm{mg} \mathrm{kg}^{-1}\right)$} \\
\hline & 0 & 400 & 800 & 1,200 & 1,600 & 2,000 \\
\hline $45 \%$ soybean meal & 32.90 & 32.90 & 32.90 & 32.90 & 32.90 & 32.90 \\
\hline Corn & 31.20 & 31.20 & 31.20 & 31.20 & 31.20 & 31.20 \\
\hline Wheat bran & 19.55 & 19.55 & 19.55 & 19.55 & 19.55 & 19.55 \\
\hline Fish meal & 5.00 & 5.00 & 5.00 & 5.00 & 5.00 & 5.00 \\
\hline Poultry viscera meal & 5.00 & 5.00 & 5.00 & 5.00 & 5.00 & 5.00 \\
\hline Soybean oil & 4.03 & 4.03 & 4.03 & 4.03 & 4.03 & 4.03 \\
\hline Limestone & 0.72 & 0.72 & 0.72 & 0.72 & 0.72 & 0.72 \\
\hline Mineral and vitamin supplement ${ }^{(1)}$ & 0.50 & 0.50 & 0.50 & 0.50 & 0.50 & 0.50 \\
\hline Dicalcium phosphate & 0.42 & 0.42 & 0.42 & 0.42 & 0.42 & 0.42 \\
\hline Common salt & 0.30 & 0.30 & 0.30 & 0.30 & 0.30 & 0.30 \\
\hline L-lysine hydrochloride & 0.26 & 0.26 & 0.26 & 0.26 & 0.26 & 0.26 \\
\hline Antifungal calcium propionate & 0.10 & 0.10 & 0.10 & 0.10 & 0.10 & 0.10 \\
\hline BHT antioxidant & 0.02 & 0.02 & 0.02 & 0.02 & 0.02 & 0.02 \\
\hline L-carnitine & 0.00 & 0.04 & 0.08 & 0.12 & 0.16 & 0.20 \\
\hline Total & 100.00 & 100.00 & 100.00 & 100.00 & 100.00 & 100.00 \\
\hline \multicolumn{7}{|l|}{ Calculated nutrients } \\
\hline Starch $(\%)$ & 30.00 & 30.00 & 30.00 & 30.00 & 30.00 & 30.00 \\
\hline Total arginine $(\%)$ & 1.81 & 1.81 & 1.81 & 1.81 & 1.81 & 1.81 \\
\hline Calcium (\%) & 1.00 & 1.00 & 1.00 & 1.00 & 1.00 & 1.00 \\
\hline Digestible energy $\left(\mathrm{kcal} \mathrm{kg}^{-1}\right)$ & 3,200 & 3,200 & 3,200 & 3,200 & 3,200 & 3,200 \\
\hline Total phenylalanine (\%) & 1.23 & 1.23 & 1.23 & 1.23 & 1.23 & 1.23 \\
\hline Total phosphorus (\%) & 0.80 & 0.80 & 0.80 & 0.80 & 0.80 & 0.80 \\
\hline Total histidine (\%) & 0.66 & 0.66 & 0.66 & 0.66 & 0.66 & 0.66 \\
\hline Total isoleucine $(\%)$ & 1.10 & 1.10 & 1.10 & 1.10 & 1.10 & 1.10 \\
\hline Total leucine (\%) & 2.08 & 2.08 & 2.08 & 2.08 & 2.08 & 2.08 \\
\hline Total lysine (\%) & 1.64 & 1.64 & 1.64 & 1.64 & 1.64 & 1.64 \\
\hline Total methionine (\%) & 0.41 & 0.41 & 0.41 & 0.41 & 0.41 & 0.41 \\
\hline Digestible protein $(\%)$ & 23.00 & 23.00 & 23.00 & 23.00 & 23.00 & 23.00 \\
\hline Total threonine $(\%)$ & 1.01 & 1.01 & 1.01 & 1.01 & 1.01 & 1.01 \\
\hline Total tryptophan (\%) & 0.32 & 0.32 & 0.32 & 0.32 & 0.32 & 0.32 \\
\hline Total valine $(\%)$ & 1.25 & 1.25 & 1.25 & 1.25 & 1.25 & 1.25 \\
\hline \multicolumn{7}{|c|}{ Analyzed chemical composition (natural matter) } \\
\hline Dry matter $(\%)$ & 93.04 & 91.71 & 89.66 & 91.72 & 91.69 & 91.69 \\
\hline Crude protein $(\%)$ & 27.11 & 27.12 & 27.93 & 27.76 & 27.06 & 26.92 \\
\hline Ethereal extract (\%) & 7.98 & 8.12 & 8.37 & 8.58 & 8.07 & 7.29 \\
\hline Mineral matter (\%) & 7.45 & 7.86 & 7.69 & 7.67 & 7.40 & 7.73 \\
\hline Gross energy ( $\mathrm{kcal} \mathrm{kg}^{-1}$ ) & 4,461 & 4,459 & 4,352 & 4,446 & 4,412 & 4,356 \\
\hline Crude fiber $(\%)$ & 5.43 & 5.99 & 5.01 & 5.10 & 5.42 & 4.97 \\
\hline
\end{tabular}

${ }^{(1)}$ Guarantee levels per kilogram of product: $500.000 \mathrm{IU}$ vitamin A, $250.000 \mathrm{IU}$ vitamin D3, $5.000 \mathrm{mg}$ vitamin E, $500 \mathrm{mg}$ vitamin $\mathrm{K} 3,1.500 \mathrm{mg}$ vitamin $\mathrm{B} 1,1.500 \mathrm{mg}$ vitamin $\mathrm{B} 2,1.500 \mathrm{mg}$ vitamin $\mathrm{B} 6,4.000 \mathrm{mg}$ vitamin B12, $500 \mathrm{mg}$ folic acid, $4.000 \mathrm{mg}$ calcium pantothenate, $10.000 \mathrm{mg}$ vitamin C, $10 \mathrm{mg}$ biotin; 1.000 inositol, 7.000 nicotinamide, $10.000 \mathrm{mg}$ choline, $10 \mathrm{mg}$ cobalt, $1.000 \mathrm{mg}$ copper, $5.000 \mathrm{mg}$ iron, $200 \mathrm{mg}$ iodine, $1.500 \mathrm{mg}$ manganese, $30 \mathrm{mg}$ selenium, and $9.000 \mathrm{mg}$ zinc. The values of gross and digestible energy, as well as of crude protein (\%), were estimated for pacu according to Abimorad \& Carneiro (2004) 
and stored under refrigerated conditions, at $-20^{\circ} \mathrm{C}$, until feeding. L-carnitine was included at the same time as the other micro-ingredients of the formulation.

The fish were acclimated for 8 days and received the experimental diet for 120 days. During the total experimental period, the fish were fed four times a day at 8:00 a.m., 11:00 a.m., 2:00 p.m., and 5:00 p.m., ad libitum. At the end of the experimental period, the fish were fasted for 24 hours to empty their gastrointestinal tract and, subsequently, desensitized in a benzocaine solution at $100 \mathrm{mg} \mathrm{L}^{-1}$ water, in order to measure their individual weight $(\mathrm{g})$ and total length $(\mathrm{cm})$. Then, three fish from each tank were euthanized in a benzocaine solution at $250 \mathrm{mg} \mathrm{L}^{-1}$ water and packed in ice for the removal of their liver, intestine, white muscle, and viscerosomatic fat. After evisceration, the fish carcasses were analyzed to determine carcass composition.

The obtained biometric values were tabulated to determine the following production performance data: average final weight (AFW, g); average final length $(\mathrm{AFL}, \mathrm{cm})$; survival $(\%)=100 \mathrm{x}$ (final fish number / initial fish number); weight gain $(\mathrm{g})$ = final body weight - initial body weight; feed conversion rate (FCR) $=$ feed supplied / weight gain; specific growth rate $(\mathrm{SGR}, \%)=100 \times[(\ln$ final weight $-\ln$ initial weight $)$ / experimental period]; protein efficiency ratio (PER, $\%)=100 \times$ (weight gain / consumed crude protein); hepatosomatic index $(\%)=100 \times$ (liver weight $/$ final body weight); and viscerosomatic fat index $(\%)=100 \mathrm{x}$ (viscerosomatic fat weight / final body weight).

For determination of carcass centesimal composition, the fish samples were pre-dried in a forced-air ventilation oven, at $55^{\circ} \mathrm{C}$, for 72 hours. Subsequently, the moisture analysis was carried out by oven drying, at $105^{\circ} \mathrm{C}$, for 8 hours. Ash content was obtained in a muffle furnace, at $550^{\circ} \mathrm{C}$, for 6 hours. Crude protein was determined by the Kjeldahl method, and the ethereal extract content was obtained using a Soxhlet extractor with ether as the solvent, all according to the methodology described by Association of Official Analytical Chemists (AOAC) (Horwitz, 2005).

For the histological analysis, with the aid of a blade, a $15-\mathrm{mm}$ white muscle sample was removed from the left side of the fish, above the lateral line. Later, the fish were eviscerated and $15-\mathrm{mm}$ samples of the median intestine and liver were collected. A total of eight fish per treatment were used. The samples were conditioned in formalin-acetic acid-alcohol solution for 24 hours and then preserved in 70\% alcohol, at $20^{\circ} \mathrm{C}$, until the analyses were performed. For processing, the samples were dehydrated in increasing concentrations of alcohol, diaphanized in xylol, and embedded in histological paraffin. For the cuts, the HM 340E Electronic Microtome (Thermo Scientific Inc., Waltham, MA, USA) was used. The taken cross sections were $5 \mu \mathrm{m}$ from the liver and $7 \mu \mathrm{m}$ from the muscle and intestine. The samples were stained using the hematoxylin-eosin method (Behmer et al.,1976).

The smallest diameter of at least 200 muscle fibers of each fish was classified according to morphometry, as $<20 \mu \mathrm{m}, 20-50 \mu \mathrm{m}$, and $>50 \mu \mathrm{m}$, in order to evaluate the contribution of hyperplasia and hypertrophy to muscle growth (Almeida et al., 2008). In the intestine, the number of hepatocytes per area $\left(2,000 \mu \mathrm{m}^{2}\right)$ was quantified, and two cuts of each liver were examined. The morphometric analyisis of the intestinal mucosa was performed in ten villi per animal, to measure villi height, total villi height, villi width, villi thickness, and tunica thickness.

Photo documentation was done using light microscopy, under the Olympus BX50 optical P1 microscope (Olympus Co., Ltd., Manila, Philippines), coupled to the Olympus PMC 35 B camera (Olympus Europa SE \& Co. KG, Hamburg, Germany), with 40X objective lens for the analysis of the muscle and liver and 20X objective lens for that of the intestine. For measurements, the cellSens, version 1.15, standard software (Olympus Corporation, Tokyo, Japan) was used.

For the analysis of thiobarbituric acid reactive substances (TBARS), glutathione-S-transferase (GST), and catalase (CAT), two fish from each tank were packed in ice for the removal of a liver sample, which was stored in liquid nitrogen for further analysis. Upon thawing, the liver was homogenized in $90 \mu \mathrm{L}$ of $0.3 \mathrm{~mol} \mathrm{~L}^{-1}$ sodium phosphate buffer $(140 \mathrm{mmol}$ $\mathrm{L}^{-1} \mathrm{KCl}, \mathrm{pH}$ 7.4) per gram of tissue. The mixture was composed of a protease inhibitor (not degrading the enzymes) and phenylmethylsulfonyl fluoride (PMSF) in a $100-\mathrm{nmol} \mathrm{L}^{-1}$ concentration diluted in isopropanol (0.03484 g PMSF in $2.0 \mathrm{~mL}$ isopropyl alcohol). A total of $10 \mu \mathrm{L}$ PMSF were added to each milliliter of the buffer.

TBARS was determined according to Buege \& Aust (1978), and the results were expressed in $\mathrm{nmol} \mathrm{\textrm {mg } ^ { - 1 }}$ malondialdehyde protein. CAT was evaluated as in

Pesq. agropec. bras., Brasília, v.55, e01583, 2020

DOI: 10.1590/S1678-3921.pab2020.v55.01583 
Nelson \& Kiesow (1972) at a wavelength of $240 \mathrm{~nm}$,

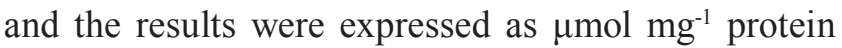
per minute. GST activity was obtained following the method of Ellman (1959), using 20\% trichloroacetic acid in the proportion $0.2 \mathrm{~g}$ tissue: $1.0 \mathrm{~mL}$ trichloroacetic acid. Readings were performed in a spectrophotometer, at a wavelength of $412 \mathrm{~nm}$, and activity was expressed in $\mu \mathrm{mol} \mathrm{L} \mathrm{Lg}^{-1} \mathrm{mg}^{-1}$ protein.

The data were subjected to Levene's test to check for normality and homoscedasticity, and, given these assumptions, were subjected to the analysis of variance, at $5 \%$ probability. When there was a significant difference, means were compared by Tukey's test, at 5\% probability, using the Statistica, version 7.1, software (TIBCO Software, Inc., Palo Alto, CA, USA).

\section{Results and Discussion}

The inclusion of L-carnitine in the diets of pacu juveniles did not affect the AFW, AFL, weight gain, survival, FCR, PER, and SGR variables (Table 2). However, it may promote the energy efficiency of fatty acids, due to the increased mitochondrial lipid oxidation. It should be noted that the obtained results may differ according to experimental conditions, studied species, fish development phase, stress conditions, among other factors (Gonçalves et al., 2010). Li et al. (2020) found that the action of L-carnitine supplementation in fish diets is directly linked to the abundance of individual macronutrients, including fatty acids, glucose, and amino acids. Therefore, the "protein-sparing effect" will be effective when the diets contain an adequate amount of lipids.

During the experimental period, the temperature remained within the recommended minimum limit for pacu cultivation, which may have hindered fish development, as supported by the indexes of weight gain and specific growth rate (Sanchez et al., 2016). Regarding the influence of temperature, Hosam et al. (2016) observed that Nile tilapia fed diets supplemented with L-carnitine showed increased survival at low temperatures, besides improved performance up to the rate of $1,200 \mathrm{mg} \mathrm{kg}^{-1}$.

The supplementation with L-carnitine also promoted an increase in the hepatosomatic index (Table 2), which is influenced by the diet and represents higher energy reserve rates and, supposedly, the deposition of fat and glycogen in the liver, indicating an increase in the weight of this organ (Barbosa et al., 2011). When studying zebrafish (Danio rerio Hamilton, 1822), Li et al. (2017) reported an improvement in lipid catabolism with the inclusion of L-carnitine in the diets, but also an increase in glycogen deposition in the entire body. These results were confirmed by the expression of a gene related to glycolysis (PFK and $\mathrm{PK}$ ) in the muscle and to gluconeogenesis (PECK1 and $\mathrm{G} 6 \mathrm{~Pa}$ ) in the liver, showing that the increase of lipid catabolism in fish decreases the energy from the degradation of glucose, causing an increased gluconeogenesis and glycogen synthesis.

When included in the diet, L-carnitine has the tendency to increase lipid oxidation in the metabolism,

Table 2. Growth performance of juvenile pacu (Piaractus mesopotamicus) after 128 days fed diets containing different levels of L-carnitine ${ }^{(1)}$.

\begin{tabular}{|c|c|c|c|c|c|c|c|}
\hline \multirow[t]{2}{*}{ Variable $^{(2)}$} & \multicolumn{6}{|c|}{ L-carnitine $\left(\mathrm{mg} \mathrm{kg}^{-1}\right)^{(3)}$} & \multirow[t]{2}{*}{ P-value } \\
\hline & 0 & 400 & 800 & 1,200 & 1,600 & 2,000 & \\
\hline $\mathrm{AFW}(\mathrm{cm})$ & $9.90 \pm 0.74$ & $9.52 \pm 0.80$ & $9.87 \pm 0.95$ & $9.27 \pm 0.35$ & $9.68 \pm 0.54$ & $9.48 \pm 0.62$ & - \\
\hline $\operatorname{AFL}(\mathrm{cm})$ & $13.19 \pm 0.63$ & $13.38 \pm 0.55$ & $13.25 \pm 0.94$ & $12.97 \pm 1.16$ & $12.92 \pm 0.71$ & $12.87 \pm 0.37$ & 0.92 \\
\hline WG (g) & $31.45 \pm 4.71$ & $32.71 \pm 3.64$ & $33.13 \pm 6.99$ & $31.17 \pm 5.83$ & $30.21 \pm 5.13$ & $30.08 \pm 2.91$ & 0.96 \\
\hline Survival (\%) & $87.50 \pm 12.50$ & $83.33 \pm 11.78$ & $85.42 \pm 10.82$ & $91.67 \pm 8.33$ & $97.92 \pm 3.61$ & $97.92 \pm 3.61$ & 0.27 \\
\hline FCR & $2.15 \pm 0.27$ & $2.20 \pm 0.58$ & $2.03 \pm 0.40$ & $2.08 \pm 0.18$ & $1.79 \pm 0.28$ & $2.09 \pm 0.15$ & 0.75 \\
\hline SGR (\%) & $1.19 \pm 0.09$ & $1.24 \pm 0.05$ & $1.22 \pm 0.08$ & $1.22 \pm 0.10$ & $1.17 \pm 0.08$ & $1.19 \pm 0.09$ & 0.92 \\
\hline PER (\%) & $0.18 \pm 0.03$ & $0.19 \pm 0.02$ & $0.20 \pm 0.05$ & $0.18 \pm 0.04$ & $0.18 \pm 0.03$ & $0.18 \pm 0.02$ & 0.96 \\
\hline HSI (\%) & $1.74 \pm 0.14 \mathrm{a}$ & $2.02 \pm 0.05 \mathrm{ab}$ & $2.24 \pm 0.34 \mathrm{~b}$ & $2.15 \pm 0.16 b$ & $2.03 \pm 0.05 \mathrm{ab}$ & $2.24 \pm 0.22 b$ & 0.003 \\
\hline VFI (\%) & $2.36 \pm 1.04 \mathrm{a}$ & $2.49 \pm 0.62 \mathrm{a}$ & $2.83 \pm 0.45 \mathrm{ab}$ & $3.21 \pm 0.72 \mathrm{ab}$ & $3.20 \pm 0.64 \mathrm{ab}$ & $3.96 \pm 0.43 b$ & 0.004 \\
\hline
\end{tabular}

${ }^{(1)}$ Means followed by equal letters do not differ by Tukey's test, at $5 \%$ probability. ${ }^{(2)} \mathrm{AFW}$, average final weight; AFL, average final length; WG, weight gain; FCR, feed conversion rate; SGR, specific growth rate; PER, protein efficiency rate; HSI, hepatosomatic index; and VFI, viscerosomatic fat index.

${ }^{(3)}$ Mean \pm standard deviation. 
promoting a lower accumulation of fat and, consequently, a high protein content in the body of fish (Yang et al., 2012). In the present study, there was a reduction in fish body fat with the supplementation of $1,600 \mathrm{mg} \mathrm{kg}^{-1} \mathrm{~L}$-carnitine, but an increase in lipid content with 2,000 mg kg-1 (Table 3). Similar results were observed for Caspian Sea Kutum (Rutilus frisii kutum Kamensky, 1901), when fed diet supplemented with different L-carnitine levels (Nekoubin et al., 2012), and for common carp (Cyprinus carpio Linnaeus, 1758) fed 1,000 $\mathrm{mg} \mathrm{kg}^{-1}$ L-carnitine (Sabzi et al., 2017). Although the mechanisms that lead L-carnitine to promote this effect are still not known, they could be related to the limit requirement of each species. After being synthesized, L-carnitine is transported to the tissues, being higher in the organisms that use fatty acids as a primary energy source (Longo et al., 2016). Therefore, after synthesis in the liver and kidneys, it is transported to the muscle where it is used in B-oxidation, being converted from free-form L-carnitine to L-carnitine ethers (Ozório et al., 2002).

The analysis of hepatocyte quantification and muscle histomorphometry showed no significant difference between the fish fed diets supplemented with L-carnitine and those fed the control (Table 4 and Figures 1 and 2). During the early stages of life, fish tissues exhibit rapid growth rates (Almeida et al., 2008). Therefore, hyperplasia (diameter $<20 \mu \mathrm{m}$ ) is very frequent during muscle development in the juvenile phase, whereas hypertrophy (diameters $>50$ $\mu \mathrm{m})$ is more frequent in adulthood (Almeida et al., 2008). Diameters smaller than $20 \mu \mathrm{m}$ represented between 30 and $38 \%$ of the diameter of the evaluated fibers (Table 4). In this case, the larger fibers started as normal and became hyperplastic, showing activity in the process of muscle growth during the developmental

Table 3. Carcass centesimal composition of juvenile pacu (Piaractus mesopotamicus) after 128 days fed diets containing different levels of L-carnitine ${ }^{(1)}$.

\begin{tabular}{|c|c|c|c|c|c|c|c|}
\hline \multirow[t]{2}{*}{ Variable } & \multicolumn{6}{|c|}{ L-carnitine $\left(\mathrm{mg} \mathrm{kg}^{-1}\right)^{(2)}$} & \multirow{2}{*}{ P-value } \\
\hline & 0 & 400 & 800 & 1,200 & 1,600 & 2,000 & \\
\hline Moisture (\%) & $70.13 \pm 1.09$ & $69.75 \pm 0.75$ & $69.52 \pm 0.67$ & $69.47 \pm 1.67$ & $69.87 \pm 0.88$ & $68.56 \pm 0.42$ & 0.59 \\
\hline Crude protein $(\%)$ & $18.73 \pm 0.75 \mathrm{a}$ & $16.37 \pm 0.75 b$ & $17.65 \pm 0.24 \mathrm{ab}$ & $16.91 \pm 0.43 b$ & $17.28 \pm 0.46 b$ & $17.75 \pm 0.29 \mathrm{ab}$ & 0.00 \\
\hline Lipids (\%) & $10.16 \pm 0.50 \mathrm{ab}$ & $10.61 \pm 0.50 \mathrm{ab}$ & $10.23 \pm 0.04 \mathrm{ab}$ & $9.90 \pm 0.29 \mathrm{ab}$ & $9.62 \pm 0.60 \mathrm{a}$ & $10.76 \pm 0.30 \mathrm{~b}$ & 0.04 \\
\hline Ash (\%) & $3.01 \pm 0.10$ & $2.98 \pm 0.04$ & $3.10 \pm 0.17$ & $3.16 \pm 0.05$ & $3.14 \pm 0.07$ & $3.15 \pm 0.13$ & 0.21 \\
\hline
\end{tabular}

${ }^{(1)}$ Means followed by equal letters do not differ by Tukey's test, at $5 \%$ probability. ${ }^{(2)}$ Mean \pm standard deviation.

Table 4. Intestinal histomorphometry, quantification of hepatocytes, and frequency of the smallest diameter of the muscle fibers of juvenile pacu (Piaractus mesopotamicus) after 128 days fed diets containing different levels of L-carnitine ${ }^{(1)}$.

\begin{tabular}{|c|c|c|c|c|c|c|c|}
\hline \multirow[t]{2}{*}{ Variable } & \multicolumn{6}{|c|}{ L-carnitine $\left(\mathrm{mg} \mathrm{kg}^{-1}\right)^{(2)}$} & \multirow[t]{2}{*}{ P-value } \\
\hline & 0 & 400 & 800 & 1,200 & 1,600 & 2,000 & \\
\hline \multicolumn{8}{|l|}{ Intestine } \\
\hline Height $(\mu \mathrm{m})$ & $399.31 \pm 92.01 \mathrm{ab}$ & $312.65 \pm 106.70 \mathrm{a}$ & $466.66 \pm 90.83 \mathrm{ab}$ & $477.78 \pm 50.42 \mathrm{ab}$ & $478.62 \pm 38.48 \mathrm{ab}$ & $539.67 \pm 48.35 b$ & 0.01 \\
\hline Total height $(\mu \mathrm{m})$ & $450.49 \pm 106.81$ & $416.15 \pm 142.99$ & $507.69 \pm 91.26$ & $528.85 \pm 41.38$ & $537.55 \pm 23.94$ & $592.86 \pm 49.47$ & 0.10 \\
\hline Width $(\mu \mathrm{m})$ & $121.97 \pm 12.20$ & $110.49 \pm 3.26$ & $122.76 \pm 18.83$ & $108.98 \pm 3.19$ & $120.42 \pm 14.11$ & $111.25 \pm 14.29$ & 0.29 \\
\hline Thickness $(\mu \mathrm{m})$ & $52.27 \pm 0.81 \mathrm{ab}$ & $56.61 \pm 6.22 \mathrm{ab}$ & $57.60 \pm 9.45 \mathrm{ab}$ & $60.93 \pm 0.98 \mathrm{ab}$ & $63.72 \pm 5.14 \mathrm{~b}$ & $50.05 \pm 4.96 \mathrm{a}$ & 0.02 \\
\hline Tunica $(\mathrm{cm})$ & $40.34 \pm 2.66 \mathrm{a}$ & $53.90 \pm 3.36 \mathrm{c}$ & $44.17 \pm 5.79 \mathrm{ab}$ & $44.42 \pm 2.24 \mathrm{ab}$ & $57.34 \pm 2.71 \mathrm{c}$ & $51.28 \pm 2.62 \mathrm{bc}$ & 0.00 \\
\hline \multicolumn{8}{|l|}{ Liver } \\
\hline Hepatocytes $^{(3)}$ & $142.00 \pm 7.57$ & $157.58 \pm 34.43$ & $136.33 \pm 19.28$ & $125.67 \pm 9.18$ & $136.50 \pm 11.79$ & $136.42 \pm 9.14$ & 0.28 \\
\hline \multicolumn{8}{|l|}{ Muscle (\%) } \\
\hline$<20 \mu \mathrm{m}$ & $30.00 \pm 4.43$ & $34.75 \pm 9.00$ & $33.50 \pm 6.49$ & $35.63 \pm 3.94$ & $38.00 \pm 11.11$ & $30.50 \pm 4.71$ & 0.60 \\
\hline $20-50 \mu \mathrm{m}$ & $66.75 \pm 4.70$ & $65.00 \pm 8.40$ & $66.00 \pm 6.42$ & $61.75 \pm 2.53$ & $61.12 \pm 11.02$ & $65.50 \pm 4.43$ & 0.79 \\
\hline$>50 \mu \mathrm{m}$ & $0.83 \pm 1.44$ & $0.50 \pm 0.86$ & $0.66 \pm 1.15$ & $1.67 \pm 1.75$ & $1.17 \pm 1.15$ & $3.00 \pm 1.32$ & 0.12 \\
\hline
\end{tabular}

${ }^{(1)}$ Means followed by equal letters do not differ by Tukey's test, at $5 \%$ probability. ${ }^{(2)}$ Mean \pm standard deviation. ${ }^{(3)}$ Average number of hepatocytes in $2,000 \mu \mathrm{m}^{2}$. 
stage, confirming the lower percentage (less than $3 \%$ ) of hypertrophic fibers.

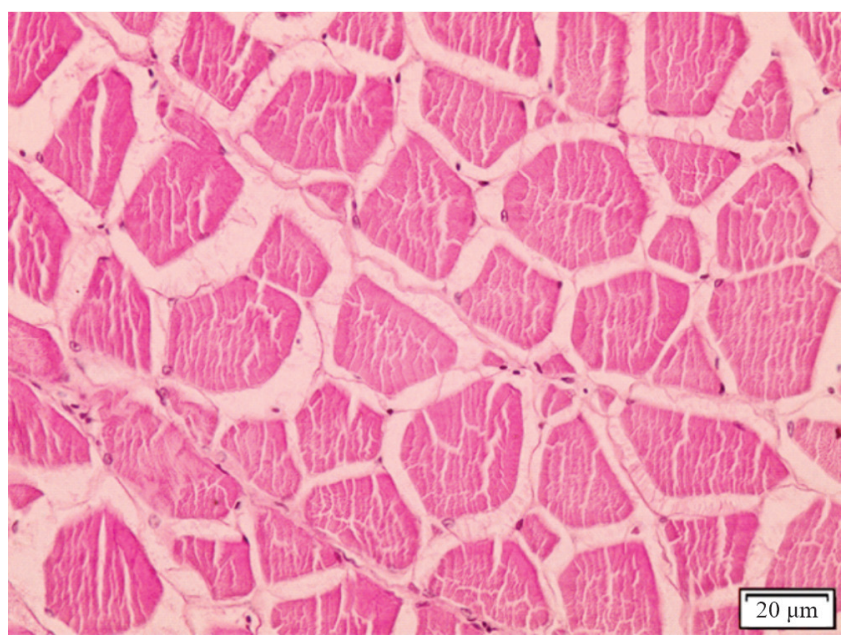

Figure 1. Histological image of the muscle tissue of pacu (Piaractus mesopotamicus) after 128 days fed diets containing different L-carnitine levels. The smallest diameter of each muscle fiber was measured using the cellSens standard software (Olympus Corporation, Tokyo, Japan), through a light microscope with 40x objective lens. The fibers were divided into three measurement classes, which showed no significant difference between the levels of dietary inclusion by Tukey's test, at $5 \%$ probability.

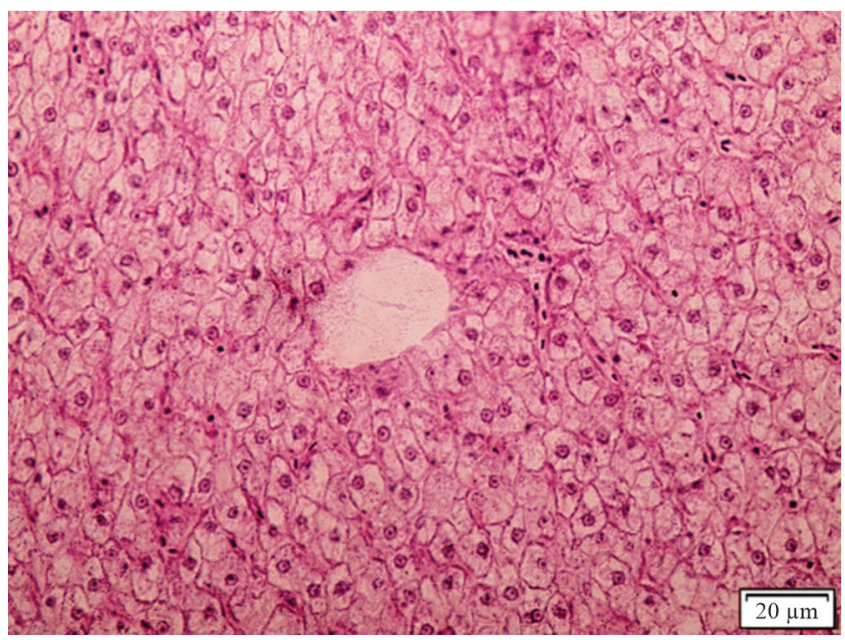

Figure 2. Histological image of the liver tissue of pacu (Piaractus mesopotamicus) after 128 days fed diets containing different L-carnitine levels. Hepatocytes were quantified using a 40x light microscope. No significant difference was observed between the levels of dietary inclusion by Tukey's test, at 5\% probability.
Fish fed 2,000 $\mathrm{mg} \mathrm{kg}^{-1}$ L-carnitine had taller and less-thick villi (Table 4 and Figure 3), which represents an adaptation of the tissue to the food, suggesting an improvement in the surface area for the absorption of nutrients (Hisano et al., 2018). In pacu, the intestine the main organ for nutrient digestion and absorption in fish - is medium sized and lined by folds, which are distributed longitudinally, being wider and more complex in the median portion, where there is a greater nutrient absorption (Corrêa, 2016). According to Yuan et al. (2011), L-carnitine can protect the intestinal wall from lesions and bacterial infections because it improves the absorption of nutrients.

L-carnitine acts on $\beta$-oxidation as a carrier of longchain fatty acids, has a regulatory function in the energy metabolism of animals, and may also act on resistance to stress due to the $\beta$-oxidation of mitochondrial fatty acids (Li et al., 2017). According to these authors, although the limited carnitine synthesis in Nile tilapia did not induce oxidative stress, it significantly inhibited the $\beta$-oxidation of mitochondrial fatty acids and decreased resistance to pathogens and nitrogenous ammonia, indicating that carnitine is necessary for the $\beta$-oxidation of mitochondrial fatty acids.

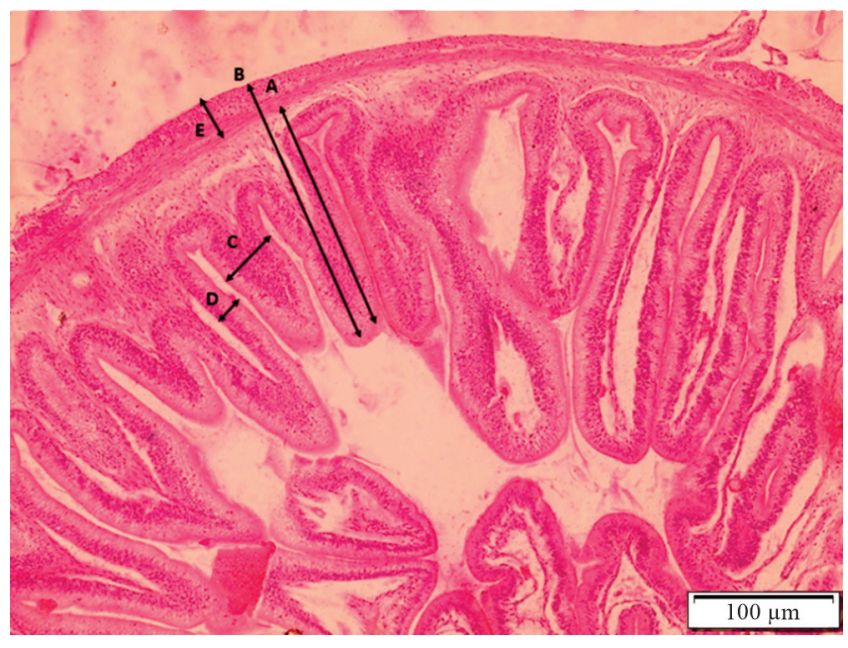

Figure 3. Image of the histological section of the intestine of pacu (Piaractus mesopotamicus) after 128 days fed diets containing different L-carnitine levels, showing: villi height (A), total villi height (B), villi width (C), villi thickness (D), and tunica thickness (E). The height and thickness of the villi and thickness of the tunica differed significantly between treatments by Tukey's test, at 5\% probability. 
Table 5. Concentration of substances reactive to catalase (CAT), glutathione S-transferase (GST), and thiobarbituric acid (TBARS) in the liver of juvenile pacu (Piaractus mesopotamicus) after 128 days fed diets containing different levels of L-carnitine ${ }^{(1)}$.

\begin{tabular}{lccccccc}
\hline Variable $^{(2)}$ & \multicolumn{5}{c}{ L-carnitine levels $\left(\mathrm{mg} \mathrm{kg}^{-1}\right)^{(3)}$} & \multicolumn{2}{c}{ P-value } \\
\cline { 2 - 6 } & \multicolumn{1}{c}{0} & \multicolumn{1}{c}{400} & 800 & 1,200 & 1,600 & 0.000 \\
\hline CAT & $0.58 \pm 0.14$ & $0.57 \pm 0.18$ & $0.58 \pm 0.18$ & $0.52 \pm 0.39$ & $0.46 \pm 0.20$ & $0.59 \pm 0.14$ \\
GST & $0.87 \pm 0.17$ & $0.90 \pm 0.06$ & $0.82 \pm 0.18$ & $0.90 \pm 0.11$ & $0.97 \pm 0.17$ & $0.88 \pm 0.14$ \\
TBARS & $1.50 \pm 0.59 \mathrm{a}$ & $1.69 \pm 1.09 \mathrm{ab}$ & $1.83 \pm 0.38 \mathrm{ab}$ & $1.50 \pm 1.29 \mathrm{a}$ & $1.00 \pm 0.37 \mathrm{a}$ & $3.57 \pm 1.26 \mathrm{~b}$ & 0.85 \\
\hline
\end{tabular}

${ }^{(1)}$ Means followed by equal letters do not differ by Tukey's test, at $5 \%$ probability. ${ }^{(2)} \mathrm{CAT}, \mu \mathrm{mol} \mathrm{mg}^{-1}$ protein per minute; GST, $\mu \mathrm{mol}$ GS-DNB min ${ }^{-1} \mathrm{mg}$ per protein; and TBARS, $\eta \mathrm{mol} \mathrm{mg}^{-1}$ protein. ${ }^{(3)} \mathrm{Mean} \pm$ standard deviation.

There was no influence of L-carnitine on the CAT and glutathione peroxidase enzymes (Table 5). Lowmolecular weight enzymes, such as CAT, glutathione peroxidase, glutathione reductase, and GST, are known to have a high antioxidant activity, which forms complex defense networks against oxidative stress (Silva et al., 2017). Moreover, even though the CAT enzyme does not act directly on lipid peroxidation products, it may affect the initial peroxidation phase, decreasing the concentrations of hydrogen peroxide (Lushchak \& Bagnyukova, 2006).

The inclusion of 2,000 $\mathrm{mg} \mathrm{kg}^{-1} \mathrm{~L}$-carnitine in the diet of pacu significantly increased TBARS (Table 5), and the viscerosomatic fat index and carcass lipid content were also higher at this rate. These substances allow measuring the lipid peroxidation in a tissue, whose high fat levels may include saturated fatty acids, which are substrates for lipid peroxidation (Yu et al., 2017). TBARS, when at a high level in the liver, indicates a reduction in the antioxidant status of fish tissues and, as representative compounds of the final products of the lipid peroxidation process, they increase and consequently cause damages to the cytoplasm (Kaur \& Jindal, 2017). Therefore, the obtained results are indicative that, up to the level of $1,600 \mathrm{mg} \mathrm{kg}^{-1}$ L-carnitine in the diet, there is no alteration in the lipid peroxidation in the hepatic tissue.

\section{Conclusion}

The inclusion of L-carnitine in the diets of pacu (Piaractus mesopotamicus) juveniles does not influence the development of the fish up to 1,600 $\mathrm{mg} \mathrm{kg}{ }^{-1}$, but increases carcass lipid levels, as well the hepatosomatic and viscerosomatic fat indexes, at $2,000 \mathrm{mg} \mathrm{kg}^{-1}$.

\section{Acknowledgments}

To Coordenação de Aperfeiçoamento de Pessoal de Nível Superior (Capes), for financial support (Finance Code 001); to Conselho Nacional de Desenvolvimento Científico e Tecnológico (CNPq), for support; and to Professors Dr. Leonardo Barcellos and Dr. Gessi Koakoski, for the time dedicated to the study and for the analyzes performed in the laboratory of Universidade de Passo Fundo (UPF).

\section{References}

ABIMORAD, E.G.; CARNEIRO, D.J. Métodos de coleta de fezes e determinação dos coeficientes de digestibilidade da fração protéica e da energia de alimentos para o pacu, Piaractus mesopotamicus (Holmberg, 1887). Revista Brasileira de Zootecnia, v.33, p.1101-1109, 2004. DOI: https://doi.org/10.1590/ S1516-35982004000500001.

ALMEIDA, F.L.A. de; CARVALHO, R.F.; PINHAL, D.; PADOVANI, C.R.; MARTINS, C.; DAL PAI-SILVA, M. Differential expression of myogenic regulatory factor MyoD in pacu skeletal muscle (Piaractus mesopotamicus Holmberg 1887: Serrasalminae, Characidae, Teleostei) during juvenile and adult growth phases. Micron, v.39, p.1306-1311, 2008. DOI: https://doi.org/10.1016/j.micron.2008.02.011.

BARBOSA, M.C.; JATOBÁ, A.; VIEIRA, F. do N.; SILVA, B.C.; MOURINO, J.L.P.; ANDREATTA, E.R.; SEIFFERT, W.Q.; CERQUEIRA, V.R. Cultivation of juvenile fat snook (Centropomus parallelus Poey, 1860) fed probiotic in laboratory conditions. Brazilian Archives of Biology and Technology, v.54, p.795-801, 2011. DOI: https://doi.org/10.1590/S151689132011000400020.

BEHMER, O.A.; TOLOSA, E.M.C. de; FREITAS NETO, A.G. de. Manual de técnicas para histologia normal e patológica. São Paulo: Edart, 1976. 241p.

BUEGE, J.A.; AUST, S.D. Microsomal lipid peroxidation. Methods in Enzymology, v.52, p.302-310, 1978. DOI: https://doi.org/10.1016/S0076-6879(78)52032-6. 
CORRÊA, R. de O. Substituição da farinha de peixe pelo concentrado proteico de soja em dietas para pacus (Piaractus mesopotamicus) e dourados (Salminus brasiliensis). 2016. 103p. Tese (Doutorado) - Universidade de São Paulo, Piracicaba.

ELLMAN, G.L. Tissue sulfhydryl groups. Archives of Biochemistry and Biophysics, v.82, p.70-77, 1959. DOI: https://doi.org/10.1016/0003-9861(59)90090-6.

EL-SAYED, A.-F.M.; ABDEL-HAKIM, N.F.; ABO-STATE, H.A.; EL-KHOLY, K.F.; AL-AZAB, D.A. Effects of L-carnitine on growth performance of Nile tilapia (Oreochromis niloticus) fingerlings fed basal diet or diets containing decreasing protein levels. Journal of American Science, v.6, p.165-172, 2010.

GONÇALVES, J.F.M.; TURINI, B.G. da S.; OZÓRIO, R.O. de A. Performance of juvenile turbot (Scophthalmus maximus) fed varying dietary L-carnitine levels at different stocking densities. Scientia Agricola, v.67, p.151-157, 2010. DOI: https://doi.org/10.1590/S0103-90162010000200004.

HARPAZ, S. L-Carnitine and its attributed functions in fish culture and nutrition - a review. Aquaculture, v.249, p.3-21, 2005. DOI: https://doi.org/10.1016/j.aquaculture.2005.04.007.

HISANO, H.; SOARES, M.P.; LUIGGI, F.G.; ARENA, A.C. Dietary $\beta$-glucans and mannanoligosaccharides improve growth performance and intestinal morphology of juvenile pacu Piaractus mesopotamicus (Holmberg, 1887). Aquaculture International, v.26, p.213-223, 2018. DOI: https://doi.org/10.1007/s10499-0170210-6.

HORWITZ, W. (Ed.). Official methods of analysis of the AOAC International. $18^{\text {th }}$ ed. Gaithersburg: AOAC International, 2005. Official Methods 920.39C, 942.05, 945.01, 950.01.

HOSAM, M.A.; MAGDY, A.S.; ABD-ELKAREM, E.E.; ABD-ELBARY, A.E. Effect of feed supplementation with L-carnitine on growth and cold tolerance of the Nile tilapia, Oreochromis niloticus. Egyptian Journal of Aquatic Biology and Fisheries, v.20, p.67-75, 2016. DOI: https://doi.org/10.21608/ ejabf.2016.10608.

KAUR, M.; JINDAL, R. Oxidative stress response in liver, kidney and gills of Ctenopharyngodon idellus (cuvier \& valenciennes) exposed to chlorpyrifos. MOJ Biology and Medicine, v.1, p.103112, 2017. DOI: https://doi.org/10.15406/mojbm.2017.01.00021.

LI, J.-M.; LI, L.-Y.; QIN, X.; NING, L.-J.; LU, D.-L.; LI, D.L.; ZHANG, M.-L.; WANG, X.; DU, Z.Y. Systemic regulation of L-carnitine in nutritional metabolism in zebrafish, Danio rerio. Scientific Reports, v.7, art.40815, 2017. DOI: https://doi.org/10.1038/srep40815.

LI, L.-Y.; LU, D.-L.; JIANG, Z.-Y.; LIMBU, S.M.; QIAO, F.; CHEN, L.-Q.; ZHANG, M.-L.; DU, Z.-Y. Dietary L-carnitine improves glycogen and protein accumulation in Nile tilapia via increasing lipid-sourced energy supply: an isotope-based metabolic tracking. Aquaculture Reports, v.17, art.100302, 2020. DOI: https://doi.org/10.1016/j.aqrep.2020.100302.

LONGO, N.; FRIGENI, M.; PASQUALI, M. Carnitine transport and fatty acid oxidation. Biochimica et Biophysica Acta (BBA) - Molecular Cell Research, v.1863, p.2422-2435, 2016. DOI: https://doi.org/10.1016/j.bbamcr.2016.01.023.
LUSHCHAK, V.I.; BAGNYUKOVA, T.V. Effects of different environmental oxygen levels on free radical processes in fish. Comparative Biochemistry and Physiology Part B: Biochemistry and Molecular Biology, v.144, p.283-289, 2006. DOI: https://doi.org/10.1016/j.cbpb.2006.02.014.

MOHSENI, M.; OZÓRIO, R.O.A. Effects of dietary L-carnitine level on growth performance, body composition and antioxidant status in beluga (Huso huso L. 1758). Aquaculture Nutrition, v.20, p.477-485, 2014. DOI: https://doi.org/10.1111/anu.12100.

NASS, R.A.R.; POVH, J.A.; FORNARI, D.C.; RIBEIRO, R.P.; BRUMATTI, R.C. Economic analysis of fish productions that use aerators in tanks: a case study in the Center-West region of Brazil. Custos e @gronegócio On line, v.16, p.358-387, 2020.

NEKOUBIN, H.; HATEFI, S.; JAVEHERI, S.; SUDAGAR, M. Effects of dietary L-carnitine supplementation on body composition and growth performance in Caspian Sea Kutum (Rutilus firsii kutum). Global Veterinaria, v.8, p.276-279, 2012.

NELSON, D.P.; KIESOW, L.A. Enthalpy of decomposition of hydrogen peroxide by catalase at $25^{\circ} \mathrm{C}$ (with molar extinction coefficients of $\mathrm{H}_{2} \mathrm{O}_{2}$ solutions in the UV). Analytical Biochemistry, v.49, p.474-478, 1972. DOI: https://doi.org/10.1016/0003-2697(72)90451-4.

NRC. National Research Council. Nutrient requirement of fish and shrimp. Washington: National Academy Press, 2011. 392p.

NUNES, C. da S.; MORAES, G.; FABRIZZI, F.; HACKBARTH, A.; ARBELÁEZ-ROJAS, G.A. Growth and hematology of pacu subjected to sustained swimming and fed different protein levels. Pesquisa Agropecuária Brasileira, v.48, p.645-650, 2013. DOI: https://doi.org/10.1590/S0100-204X2013000600010.

OZÓRIO, R.O.A.; BOOMS, G.H.R.; HUISMAN, E.A.; VERRETH, J.A.J. Changes in amino acid composition in the tissues of African catfish (Clarias gariepinus) as a consequence of dietary L-carnitine supplements. Journal of Applied Ichthyology, v.18, p.140-147, 2002. DOI: https://doi.org/10.1046/ j.1439-0426.2002.00317.x.

PRODUÇÃO DA PECUÁRIA MUNICIPAL 2018. Rio de Janeiro: IBGE, v.46, p.1-8, 2018.

RAMOS FILHO, M.M.; RAMOS, M.I.L.; HIANE, P.A.; SOUZA, E.M.T. de. Perfil lipídico de quatro espécies de peixes da região pantaneira de Mato Grosso do Sul. Ciência e Tecnologia de Alimentos, v.28, p.361-365, 2008. https://doi.org/10.1590/S010120612008000200014.

RODRIGUES B, R.; MEURER, F.; BOSCOLO, W.R. Aditivos na nutrição de peixes. Revista Colombiana de Ciencia Animal, v.7, p.228-236, 2015.

SABZI, E.; MOHAMMADIAZARM, H.; SALATI, A.P. Effect of dietary L-carnitine and lipid levels on growth performance, blood biochemical parameters and antioxidant status in juvenile common carp (Cyprinus carpio). Aquaculture, v.480, p.89-93, 2017. DOI: https://doi.org/10.1016/j.aquaculture.2017.08.013.

SAFARI, O.; ATASH, M.M.S.; PAOLUCCI, M. Effects of dietary L-carnitine level on growth performance, immune responses and stress resistance of juvenile narrow clawed crayfish, Astacus 
leptodactylus Eschscholtz, 1823. Aquaculture, v.439, p.20-28, 2015. DOI: https://doi.org/10.1016/j.aquaculture.2015.01.019.

SANCHEZ, M.S. dos S.; NASCIMENTO, M. dos S.; HISANO, H. Substituição do milho pelo sorgo em dietas para juvenis de pacu. Pesquisa Agropecuária Brasileira, v.51, p.1-8, 2016. DOI: https://doi.org/10.1590/S0100-204X2016000100001.

SILVA, T.V.N. da; BARBAS, L.A.L.; TORRES, M.F.; SAMPAIO, L.A.; MONSERRAT, J.M. Lipid peroxidation and antioxidant capacity in Peckoltia oligospila (Günther, 1864) submitted to transport under different concentration of dissolved oxygen. Aquaculture, v.481, p.72-78, 2017. DOI: https://doi.org/10.1016/j. aquaculture.2017.08.024.

TAVARES, L.H.S.; SANTEIRO, R.M. Fish farm and water quality management. Acta Scientiarum. Biological Sciences, v.35, p.2127, 2013. DOI: https://doi.org/10.4025/actascibiolsci.v35i1.10086.

TONINI, W.C.T.; MENDONÇA, P.P.; POLESE, M.F.; ABREU, M.L.C.; MATOS, D.C.; VIDL JR, M.V.; ANDRADE, D.R. Níveis de carnitina na ração no desempenho corporal de tricogáster léri (Trichogaster leeri bleeker, 1852). Arquivo Brasileiro de Medicina Veterinária e Zootecnia, v.63, p.1526-1532, 2011. DOI: https://doi.org/10.1590/S0102-09352011000600033.

VAZ, M.M.; TORQUATO, V.C.; BARBOSA, N.D. de C. (Org.). Guia ilustrado de peixes da Bacia do Rio Grande. Belo Horizonte: Cemig: Cetec, 2000. 141p.
WRAY-CAHEN, D.; FERNÁNDEZ-FÍGARES, I.; VIRTANEN, E.; STEELE, N.C.; CAPERNA, T.J. Betaine improves growth but does not induce whole body or hepatic palmitate oxidation in swine (Sus scrofa domestica). Comparative Biochemistry and Physiology Part A: Molecular \& Integrative Physiology, v.137, p.131-140, 2004. DOI: https://doi.org/10.1016/j.cbpb.2003.09.015.

YANG, S.-D.; LIU, F.-G.; LIOU, C.-H. Effects of dietary L-carnitine, plant proteins and lipid levels on growth performance, body composition, blood traits and muscular carnitine status in juvenile silver perch (Bidyanus bidyanus). Aquaculture, v.342-343, p.48-55, 2012. DOI: https://doi.org/10.1016/j. aquaculture.2012.02.002.

YU, D.-H.; CHANG, J.-Z.; DONG, G.-F.; LIU, J. Replacement of fish oil with soybean oil in diets for juvenile Chinese sucker (Myxocyprinus asiaticus): effects on liver lipid peroxidation and biochemical composition. Fish Physiology and Biochemistry, v.43, p.1413-1420, 2017. DOI: https://doi.org/10.1007/s10695-0170381-0.

YUAN, Y.; GUO, H.; ZHANG, Y.; ZHOU, D.; GAN, P.; LIANG, D.M.; CHEN, J.Y. Protective effects of L-carnitine on intestinal ischemia/reperfusion injury in a rat model. Journal of Clinical Medicine Research, v.3, p.78-84, 2011. DOI: https://doi.org/10.4021/jocmr540w. 